\title{
Sistem Pakar Deteksi Tingkat Kesuburan Tanah Menggunakan Fuzzy Logic
}

\author{
Ahmad Nidomudin ${ }^{1}$, Achmadi Prasita Nugroho ${ }^{2}$, Mohammad Nur Cholis ${ }^{3}$ \\ 1'awdan.ahmad321@gmail.com, 2masterkey.indonesia@gmail.com, ${ }^{3}$ cholis8918@gmail.com
}

Program Studi Teknik Informatika, Fakultas Teknologi Informasi, Universitas Merdeka Pasuruan

\begin{abstract}
In the agricultural sector, land is a factor that plays a very important role in determining agricultural business, in each region has a different soil fertility rate and depends on the type of land and geographical location of an area. Land fertility is one of the determinants of the success of agricultural business. Processing of land is not in accordance with the characteristics of the type of plant can cause the plant easily withered and plant growth is not optimal. These factors are often the main cause of crop failure that is not known by farmers. Therefore, designed an expert system of soil fertility detector for plant species using fuzzy logic method. One method that can be applied is with fuzzy logic where each plant has a tolerance of life value to grow well while the value of land aspects are also not the same from every farmer land, Defuzzyfikasi is the right way so that the determination of the type of plant according to data from experts Is expected to assist farmers in choosing the right types of plants in accordance with a certain level of soil fertility. The measurement results obtained are in accordance with the calculation and land criteria that have been in certain areas.
\end{abstract}

Intisari-Pada sektor pertanian, tanah merupakan faktor yang berperan sangat penting dalam menentukan usaha pertanian. Kesuburan tanah adalah salah satu faktor penentu keberhasilan usaha pertanian. Setiap daerah memiliki tingkat kesuburan tanah yang berbeda-beda dan bergantung pada jenis tanah dan letak geografinya. Pengolahan tanah yang tidak tepat dengan karateristik jenis tanaman dapat mengakibatkan tanaman mudah layu dan pertumbuhan tanaman tidak maksimal. Faktor tersebut kerap sekali menjadi penyebab utama terjadinya gagal panen yang tidak diketahui oleh petani. Setiap tanaman mempunyai toleransi nilai kehidupan untuk tumbuh dengan baik sedangkan nilai aspek-aspek tanah juga tidak sama dari setiap tanah petani. Penelitian ini menyajikan perancangan sistem pakar deteksi tingkat kesuburan tanah untuk jenis tanaman menggunakan metode fuzzy logic digunakan untuk menentukan jenis tanaman sesuai data dari pakar pertanian, yang diharapkan dapat membantu petani dalam memilih jenis tanaman yang tepat sesuai dengan tingkat kesuburan tanah tertentu. Hasil pengukuran yang diperoleh sudah sesuai dengan perhitungan dan kriteria tanah yang telah dilakukan di daerah tertentu.

Kata Kunci-Tanah, Kesuburan Tanah, Jenis Tanaman, Sistem Pakar, Fuzzy Logic.

\section{PENDAhUluan}

Pada sektor pertanian, tanah merupakan faktor yang berperan sangat penting dalam menentukan usaha pertanian. Setiap daerah memiliki tingkat kesuburan tanah yang berbeda- beda dan tergantung dari jenis tanah dan letak geografis suatu daerah [1]. Kesuburan tanah merupakan salah satu faktor penentu keberhasilan usaha pertanian. Namun ada kalanya banyak usaha pertanian yang gagal atau hasil tidak maksimal karena kurangnya pemahaman tentang tingkat kesuburan tanah meraka untuk jenis tanaman tepat dan sesuai dengan sampel tanah dari petani sendiri. Kurangnya pengetahuan dan pemahaman petani akan tingkat kesuburan tanah yang tidak sama satu sama lain untuk ditanami jen is tanaman yang tepat membuat petani kesulitan dalam menentukan jenis tanaman yang tepat untuk mereka tanam. Untuk memperoleh semua pengetahuan yang diperlukan tentunya dibutuhkan waktu yang cukup lama [5][6].

Sistem pakar dalam bidang pertanian dapat membantu petani untuk membuat keputusan melalui pemilihan jenis tanaman yang sesuai sebelum mulai melakukan apapun terhadap lahan pertanian petani [3]. Di samping itu dapat membantu proses penyebaran informasi dan pengetahuan melalui aplikasi yang dapat diakses kapan saja oleh petani, logika Fuzzy digunakan dalam penelitian ini untuk dapat mengatasi banyak data yang nilainya mengandung ketidak pastian (uncertainty) data yang dimasukkan oleh petani dari setiap aspek tanah yang telah diuji di laboratorium [2]. Penelitian ini dilakukan di Kantor Ketahanan Tanaman Pangan Dinas Pertanian Pemerintahan Kabupaten Pasuruan dan kawasan pertanian Desa Tambak Rejo, Kecamatan Kraton, Kabupaten Pasuruan.

\section{PENELITIAN TERKAIT}

Pengguaan sistem pakar dalam bidang pertanian telah banyak dilakukan. Salah satunya penggunaan sistem pakar dengan menggunakan fuzzy telah dilakukan, diantara penelitian tentang implementasi mesin inferensi fuzzy untuk mendiagnosa penyakit tanaman cabe. Pada penelitian tersebut di buat sebuah alat bantu bagi petani dalam menentukan penyakit pada tanaman cabe serta bagaimana mengendalikan agar tidak keliru dalam memeaki pestisida [2]. Penelitian lain adalah penggunakan sistem pakar untuk menentukan kesesuaian lahan pertanian untuk pembudidayaan tanaman buah-buahan menggunakan forward chaining. Penelitian tersebut berguna sebagai media konsultasi mengenai penentuan kesesuaian lahan pertanian untuk pembudidayaan tanaman buah-buahan disertai dengan jenis penyakit yang sering menyerang tanaman dan cara penanaman tanaman buah-buahan. Informasi yang dihasilkan berbasis pada kriteria lahan yang ada, sehingga keputusan yang dibuat oleh sistem untuk jenis tanaman buah mengacu pada kriteria lahan tersebut dilengkapi dengan cara penanaman dan penyakit yang sering menyerang tanaman buah-buahan. Hasil uji coba menunjukan bahwa aplikasi layak dan dapat digunakan [3]. 
Untuk itu dalam penelitian ini membuat sebuah sistem pakar yang dapat menentukan kesesuaian tingkat kesuburan tanah bagi jenis tanaman pangan tertentu. Sistem pakar ini diharapkan akan dapat membantu mengurangi resiko kesalahan pemilihan jenis tanaman pangan yang akan ditanam pada suatu lahan tertentu dengan cara melihat nilai aspek tanah Jumlah parameter yang digunakan ialah 5 variabel aspek tanah. Penelitian ini juga hanya dapat memberikan satu rekomendasi jenis tanaman yang tepat untuk aspek tanah sesuai dengan data kecocokan hidup tanaman serta hanya dapat menanalisa dimana sampel tanah diambil dengan kesesuaian jenis tanaman tertentu di Kecamatan Kraton, Kabupaten Pasuruan. Metode [4] yang digunakan adalah fuzzy logic, dimana setiap tanaman mempunyai toleransi nilai kehidupan untuk tumbuh dengan baik.

\section{METODE PENELITIAN}

Penelitian ini termasuk penelitian kuantitatif. Pendekatan analisis kuantititif terd iri atas perumusan masalah, menyusun model, mendapatkan data, menguji solusi, menganalisa hasil dan menginterprestasikan hasil [4].

\section{A. Analisa Data}

Sistem pendeteksi tingkat kesuburan tanah ini menggunakan aspek tanah sebagai tolak ukur dalam menentukan ketepatan jenis tanaman dengan metode fuzzy logic. Terdapat 5 aspek unsur tanah yang akan menjadi Masukan atau inputan sistem yaitu :

\section{Variabel Oksigen Tanah}

Setiap tanah memiliki ruang pori-pori (pore space), yang nantinya akan diisi oleh udara dan air. Pada tanah yang subur dan gembur serta ditumbuhi dengan baik oleh tanaman, dengan ciri ruang pori-pori mencapai 50\%. Dengan perbandingan antara air dan udara 1:1 [5]. Himpunan domain yang digunakan pada penelitian ini untuk setiap tanaman sebagaiberikut terdapat pada Tabel 1:

TABEL 1

Variabel Oksigen tanah

\begin{tabular}{|l|c|}
\hline \multicolumn{1}{|c|}{ Himpunan } & Domain \\
\hline Cabai, Kacang tanah & {$[35,50]$} \\
\hline Padi, Kedelai, Semangka & {$[51,60]$} \\
\hline Jagung & {$[61,75]$} \\
\hline
\end{tabular}

\section{Variabel Keasaman Tanah}

Salah satu parameter tanah yang mempengaruhi tingkat kesuburan tanah adalah Keasaman $(\mathrm{pH})$ yang dinyatakan dalam kisaran 1 sampai 14. Nilai pH tanah netral adalah 7, jadi kurang dari 7 dikatakan- asam dan lebih dari 7 dikatakan basa. Hampir semua tanaman dapat tumbuh dan lebih suka berke mbang pada tanah sedikit asam dan sedikit basah antara pH 5,5 - 7,5 tergantung pada jenis tanamannya [5].

TABEL 2

Variabel Keasaman Tanah

\begin{tabular}{|l|l|}
\hline \multicolumn{1}{|c|}{ Himpunan } & Domain \\
\hline Padi, Kedelai, Semangka, Jagung & {$[5.6,6.5]$} \\
\hline Cabai, Kacang tanah & {$[6.6,7.5]$} \\
\hline
\end{tabular}

\section{Variabel Kelembapan Tanah}

Kadar air didalam tanah mempunyai peranan penting bagi semua proses-proses didalam tanah baik yang bersifat fisika, kimia dan biologi. Tanaman untuk pertumbuhannya memerlukan kadar air sebagai zat pelarut dalam pengambilan dan pengangkutan unsurhara dari tanah ketubuh tanaman [6].
TABEL 3

Variabel Kelembapan Tanah

\begin{tabular}{|l|c|}
\hline \multicolumn{1}{|c|}{ Himpunan } & Domain \\
\hline Jagung & {$[40,60]$} \\
\hline Padi, Kedelai, Semangka & {$[61,70]$} \\
\hline Cabai, Kacang Tanah & {$[71,80]$} \\
\hline
\end{tabular}

\section{Variabel Suhu Tanah}

Suhu tanah merupakan hasil dari keseluruhan radiasi yang merupakan kombinasi emisi panjang gelombang dan aliran panas dalam tanah. Suhu tanah yang rendah dapat mempengaruhi penyerapan air dari pertumbuhan tumbuhan. Jika suhu tanah rendah, kecil kemungkinan terjadi transpirasi dan dapat mengakibatkan tu mbuhan mengalami dehidrasi atau kekurangan air [5].

TABEL 4

Variabel Suhu Tanah

\begin{tabular}{|l|c|}
\hline \multicolumn{1}{|c|}{ Himpunan } & Domain \\
\hline Cabai & {$[10,22]$} \\
\hline Padi, Kacang Tanah & {$[23,27]$} \\
\hline Kedelai, Semangka, Jagung & {$[28,36]$} \\
\hline
\end{tabular}

\section{Variabel Tekstur tanah}

Tekstur tanah merupakan perbandingan fraksi pasir, debu, dan liat dalam suatu massa tanah [5].

TABEL 5

Variabel Tekstur Tanah

\begin{tabular}{|l|c|c|}
\hline Jenis Tekstur Tanah & \multicolumn{2}{|c|}{ Domain } \\
\hline Pasir Kasar & $\begin{array}{c}\text { Batas Nilai } \\
\text { Minimum }\end{array}$ & Batas Nilai Maksimum \\
\hline Pasir Halus & $0.2 \mathrm{~mm}$ & $2.0 \mathrm{~mm}$ \\
\hline Liat / lembung & $0.02 \mathrm{~mm}$ & $0.2 \mathrm{~mm}$ \\
\hline
\end{tabular}

\section{B. Analisa Derajat Keanggotaan}

\section{1) Fungsi Derajat Keanggotaan Variabel Oksigen Tanah}

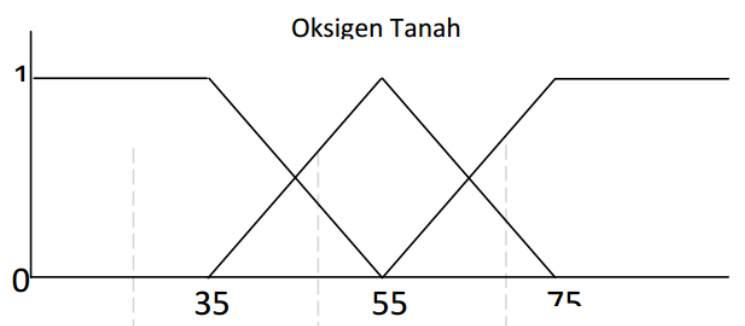

Gambar 1 Fungsi Keanggotaan Oksigen Tanah

Pada Gambar 1 Untuk menghitung nilai x Oksigen Tanah, dapat dinyatakan dalam persamaan sebagai berikut :

$$
\begin{gathered}
{[x]\left\{\begin{array}{cc}
1, & x=0 \\
\frac{35-x}{35}, & 0<x<35 \\
0, & x \geq 35
\end{array}\right.} \\
{[x]\left\{\begin{array}{cc}
0, & x \leq 35 \\
\frac{x-35}{55-35}, & 35<x<55 \\
1, & x=55 \\
\frac{75-x}{75-55}, & 55<x<75 \\
0, & x \geq 75 \\
0, & x \leq 55
\end{array}\right.} \\
{[x]\left\{\begin{array}{cc}
\frac{x-55}{75-55}, & 55<x<75 \\
1, & x \geq 75
\end{array}\right.}
\end{gathered}
$$

\section{Fungsi Derajat Keanggotaan Keasaman Tanah}

Pada Gambar 2 dibawah ini merupakan fungsi keanggotaan keasaman tanah untuk menghitung nilai $\mathrm{x}$ 
Keasaman Tanah, dapat dinyatakan dalam persamaan sebagai berikut :

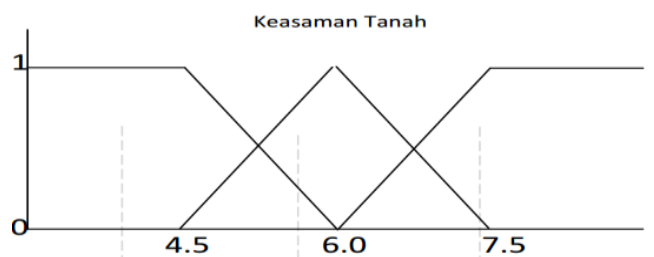

Gambar 2 Fungsi KeanggotaanKeasaman Tanah

$$
\begin{gathered}
{[x]\left\{\begin{array}{rc}
1, & x=0 \\
\frac{4,5-x}{4,5-0}, & 0<x<4,5 \\
0, & x \geq 4,5
\end{array}\right.} \\
{[x]\left\{\begin{array}{rr}
0, & x \leq 4,5 \\
\frac{x-4,5}{6,0-4,5}, & 4,5<x<6,0 \\
1, & x=6,0 \\
\frac{7,5-x}{7,5-6,0}, & 6,0<x<7,5 \\
0, & x \geq 7,5
\end{array}\right.} \\
{[x]\left\{\begin{array}{rr}
0, & x \leq 6,0 \\
\frac{x-6,0}{7,5-6,0}, & 6,0<x<7,5 \\
1, & x \geq 7,5
\end{array}\right.}
\end{gathered}
$$

\section{Fungsi Derajat Keanggotaan Kelembapan Tanah}

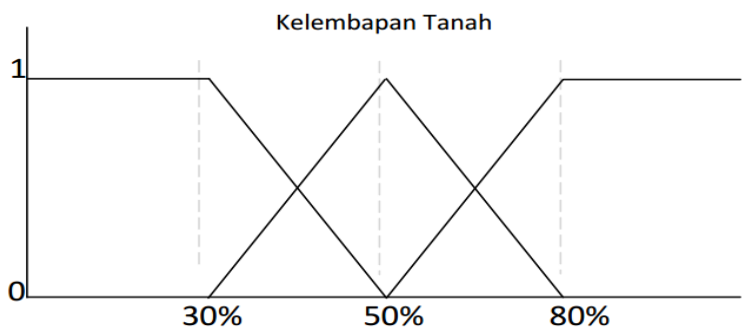

Gambar 3 Fungsi Keanggotaan Kelembapan Tanah

Pada Gambar 3 Untuk menghitung nilai x Kelembapan Tanah, dapat dinyatakan dalam persamaan sebagai berikut :

$$
\begin{gathered}
{[x]\left\{\begin{array}{cc}
1, & x=0 \\
\frac{30-x}{30-0}, & 0<x<30 \\
0, & x \geq 30
\end{array}\right.} \\
{[x]\left\{\begin{array}{cc}
0, & \leq 30 \\
\frac{x-30}{50-30}, & 30<x<50 \\
1, & x=50 \\
\frac{80-x}{80-50}, & 50<x<80 \\
0, & x \geq 80 \\
0, & x \leq 50
\end{array}\right.} \\
{[x]\left\{\begin{array}{cc}
\frac{x-50}{80-50}, & 50<x<80 \\
1, & x \leq 80
\end{array}\right.}
\end{gathered}
$$

\section{Fungsi Derajat Keanggotaan Suhu Tanah}

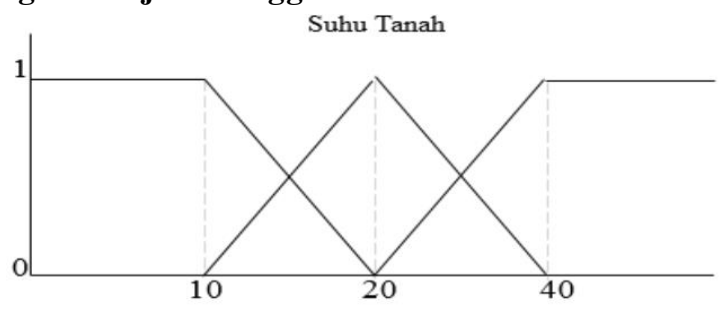

Gambar 4 Fungsi Keanggotaan Suhu Tanah

Pada Gambar 4 Untuk menghitung nilai x Suhu Tanah, dapat dinyatakan dalam persamaan sebagai berikut :

$$
\begin{aligned}
& {[x]\left\{\begin{array}{cc}
1, & x=0 \\
\frac{10-x}{10-0}, & 0<x<10 \\
0, & x \geq 10
\end{array}\right.} \\
& {[x]\left\{\begin{array}{rr}
\frac{x-10}{20-10}, & x \leq 10 \\
1, & x=20 \\
\frac{40-x}{40-20}, & 20<x<40 \\
0, & x \geq 40
\end{array}\right.} \\
& {[x]\left\{\begin{array}{rr}
\frac{x-20}{40-20}, & x \leq 20 \\
1, & x \geq 4040
\end{array}\right.}
\end{aligned}
$$

\section{Rule}

Rule ini sebagai alat bantu untuk mengetahui jenis tanaman yang tepat pada kondisi tanah yang akan di analisa. Aturan rule dituliskan dalam bentuk (IF-THEN), data aturan yang digunakan dalam menganalisis menggunakan metode fuzzy logic.

TABEL 6

Rule Fuzzy untuk Jenis Tanaman

\begin{tabular}{|c|c|c|c|c|c|c|}
\hline Rule & $\mathrm{O}_{2}(\%)$ & $\begin{array}{c}\text { Tekstur } \\
(\mathrm{mm})\end{array}$ & $\begin{array}{c}\text { Kelembapan } \\
(\%)\end{array}$ & $\begin{array}{c}\text { Suhu } \\
(\mathrm{C})\end{array}$ & $\begin{array}{c}\text { Keasaman } \\
(\mathrm{pH})\end{array}$ & $\begin{array}{c}\text { Jenis } \\
\text { Tanaman }\end{array}$ \\
\hline 1 & $35-50$ & $\begin{array}{c}0.02- \\
0.1\end{array}$ & $71-80$ & $\begin{array}{c}10- \\
22\end{array}$ & $6.6-7.5$ & Cabai \\
\hline 2 & $61-75$ & $0.2-2.0$ & $40-60$ & $\begin{array}{c}28- \\
36\end{array}$ & $5.6-6.5$ & Jagung \\
\hline 3 & $51-60$ & $0.2-2.0$ & $61-70$ & $\begin{array}{c}23- \\
27\end{array}$ & $5.6-6.5$ & Padi \\
\hline 4 & $35-50$ & $\begin{array}{c}0.02- \\
0.1\end{array}$ & $71-80$ & $\begin{array}{c}23- \\
27\end{array}$ & $6.6-7.5$ & $\begin{array}{c}\text { Kacang } \\
\text { Tanah }\end{array}$ \\
\hline 5 & $51-60$ & $0.2-2.0$ & $61-70$ & $\begin{array}{c}28- \\
36\end{array}$ & $5.6-6.5$ & Kedelai \\
\hline 6 & $51-60$ & $0.2-2.0$ & $61-70$ & $\begin{array}{c}23- \\
27\end{array}$ & $5.6-6.5$ & Semangka \\
\hline
\end{tabular}

\section{Flowchart Sistem Aplikasi}

Secara umum, alur proses sistem pendeteksi tingkat kesuburan tanah pada jenis tanaman ini dapat dilihat pada gambar dibawah ini, deskripsi dari alur sistem aplikasi tersebut adalah sebagaiberikut:

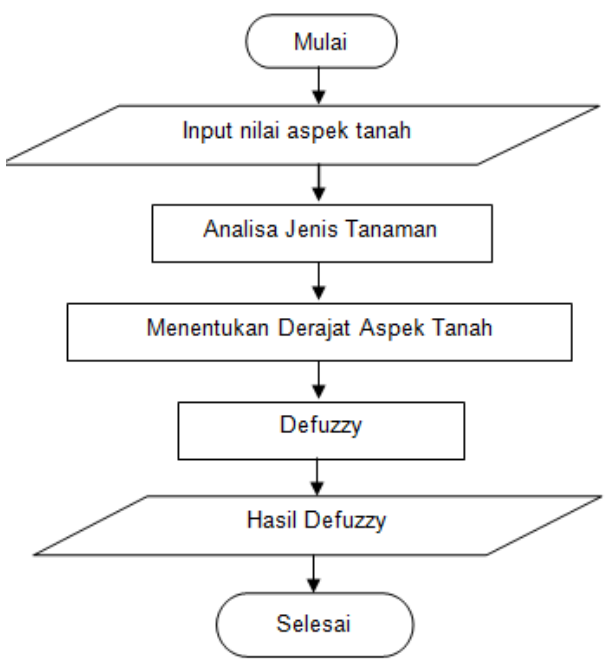

Gambar 5 Flowchart Sistem

Adapun penjelasan dari flowchart pada gambar diatas adalah sebagaiberikut:

- Input jenis tanaman : Jenis tanaman di inputkan terlebih dahula oleh pakar. 
- Input aspek-aspek tanah : Inputan tersebut diambil dari sampel tanah hasil pemeriksaan laboratorium. Inputan aspek-aspek tanah tersebut meliputi oksigen, kelembapan, keas aman, tekstur, dan suhu tanah.

- Analisa Jenis tanaman : Sistem akan menganalisa jenis tanaman dari inputan yang telah dimasukkan sesuai pada sampel tanah yang akan dianalisa.

- Menentukan derajat kriteria tanah : Dari hasil analisa jenis tanaman, sistem akan memperoleh derajat keanggotaan dari oksigen, kelembapan, keasaman, tekstur, suhu tanah, yang nantinya akan didefuzzikasikan.

- Defuzzifikasi : Setelah mendapatkan nilai dari setiap derajat keanggotaan, sistem akan mendefuzzikasikan semua nilai derajat keanggotaan as pek-aspektanah.

- Hasil proses : Setelah melewati rangkaian proses, akan didapatkan hasil proses yang berupa hasil rekomondasi jenis tanaman pada kondisi tanah tertentu sesuai sampel tanah yang dianalisa.

\section{E. Context Diagram (CD)}

Diagram ini mempresentasikan atau menggambarkan hubungan antara sistem dengan pengguna sistem (petani dan admin) yang mempengaruhi operasi sistem. Adapun perancangan diagram konteks pada system pakar ini dapat dilihat pada gambar dibawah ini:

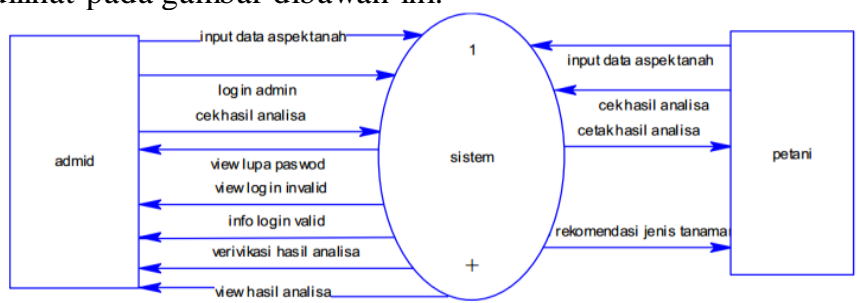

Gambar 6 Diagram Konteks

\section{F. Entity Relationship Diagram (ERD)}

Pada proses ini elemen-elemen data dikelompokkan menjadi satu field database beserta entitas dan hubungannya. Berikut relasi sistem yang dapat dilihat pada Gambar 7 .

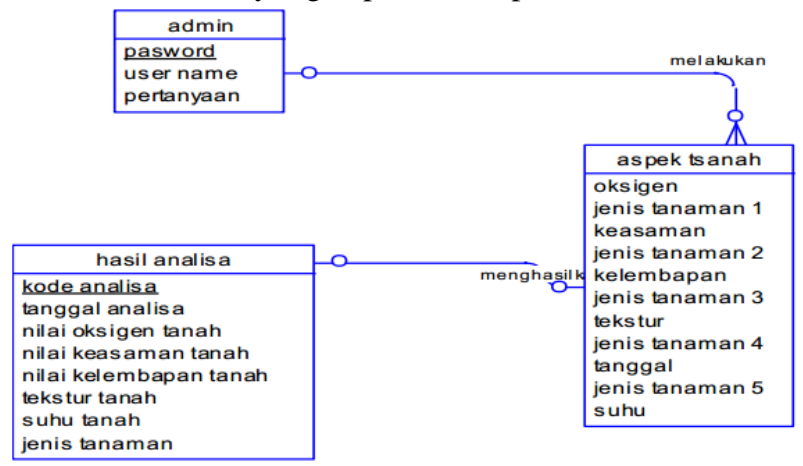

Gambar 7 Entity Relationship Diagram (ERD)

\section{HASIL DAN PEMBAHASAN}

\section{A. Implementasi Antarmuka Aplikasi}

Halaman input data aspek tanah ini sistem dapat menambah, menghapus, dan mencetak rekap hasil input data as pek tanah pada Gambar 8 .

Untuk menganalisa sampel tanah yang akan dideteksi jenis tanamannya, yaitu dengan menginputkan nilai-nilai aspek tanah sesuai data sampel tanahnya dapat dilaku kan di halaman analisa jenis tanaman seperti pada Gambar 9. Kemudian hasil rekomondasi jenis tanaman yang sebelumnya telah diinputkan petani pada halaman analisa jen is tanaman dapat dilihat di halaman hasil analisa.

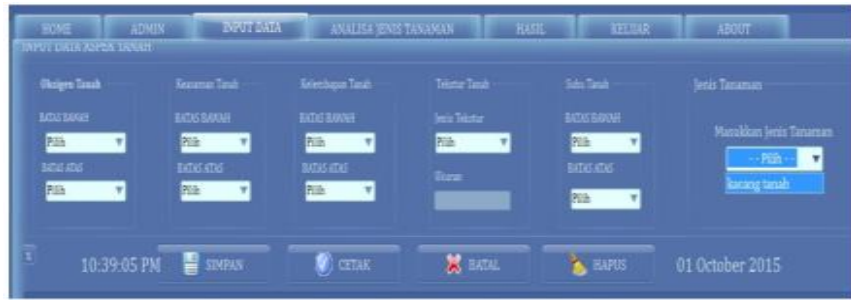

Gambar 8 Tampilan Halaman Input Data Aspek Tanah

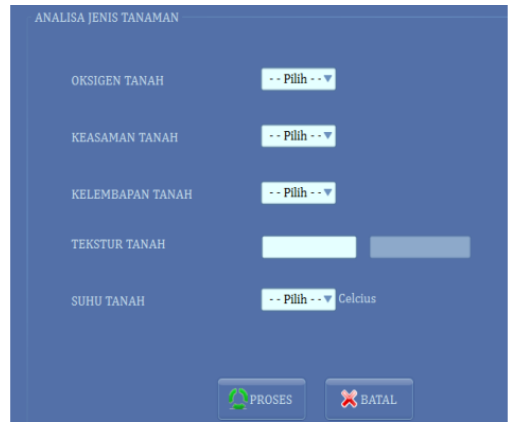

Gambar 9 Tampilan Halaman Analisa Jenis Tanaman

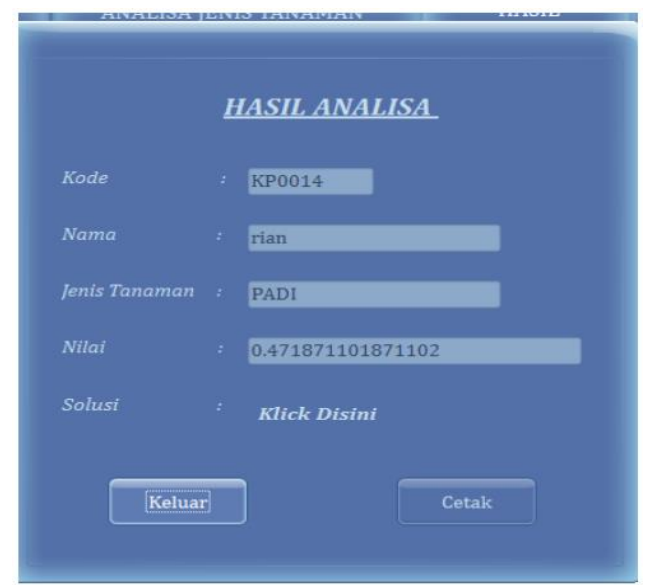

Gambar 10 Tampilan Hasil Analisa Jenis Tanaman

\section{B. Pengujian Sistem}

TABEL 7

Pengujian input data

\begin{tabular}{|c|c|c|c|c|}
\hline \multicolumn{2}{|l|}{ Test ID } & \multicolumn{3}{|l|}{ TP4PID } \\
\hline \multicolumn{2}{|c|}{\begin{tabular}{|l|} 
Tujuan Test \\
\end{tabular}} & \multicolumn{3}{|c|}{ Melakukan Uji Coba Input Data Aspek Tanah } \\
\hline \multicolumn{2}{|c|}{\begin{tabular}{|l|} 
Kondisi Awal \\
\end{tabular}} & \multicolumn{3}{|c|}{ Sistem Menampilkan Form Input Data Aspek Tanah } \\
\hline \begin{tabular}{|c|} 
Skenario \\
Pengujian
\end{tabular} & $\begin{array}{l}\text { Prosedur } \\
\text { Pengujian }\end{array}$ & $\begin{array}{c}\text { Hasil yang } \\
\text { diharapkan }\end{array}$ & $\begin{array}{l}\text { Hasil yang } \\
\text { diperoleh }\end{array}$ & Kesimpulan \\
\hline $\begin{array}{l}\text { Menguji } \\
\text { proses } \\
\text { input data } \\
\text { kriteria } \\
\text { aspek } \\
\text { tanah } \\
\text { berdasarka } \\
\text { n data } \\
\text { yang } \\
\text { diperoleh } \\
\text { dari pakar }\end{array}$ & $\begin{array}{l}\text { Admin } \\
\text { memasukkan nilai } \\
\text { kriteria-kriteria } \\
\text { Oksigen, } \\
\text { Kelembapan, } \\
\text { Suhu, Tekstur, } \\
\text { Keasaman Tanah, } \\
\text { serta memilih } \\
\text { rekomendasi jenis } \\
\text { tanaman pada } \\
\text { setiap kriteria } \\
\text { aspek tanah yang } \\
\text { dimasukkan. }\end{array}$ & $\begin{array}{l}\text { Sistem berhasil } \\
\text { menyimpan data } \\
\text { kriteria aspek } \\
\text { tanah yang telah } \\
\text { dimasukkan oleh } \\
\text { admin, } \\
\text { berdasarkan data } \\
\text { yang diperoleh } \\
\text { dari pakar }\end{array}$ & $\begin{array}{l}\text { Sistem berhasil } \\
\text { menyimpan data } \\
\text { kriteria aspek tanah } \\
\text { yang telah } \\
\text { dimasukkan oleh } \\
\text { admin, berdasarkan } \\
\text { data yang diperoleh } \\
\text { dari pakar }\end{array}$ & \begin{tabular}{|l|} 
Data kriteria \\
aspek tanah \\
berhasil \\
disimpan \\
sesuai \\
dengan data \\
yang \\
diperoleh \\
dari pakar
\end{tabular} \\
\hline
\end{tabular}


Pengujian pertama dilakukan pada proses input data ini diharapkan dapat berfungsi sesuai dengan yang diharapkan, sehingga data dalam sistem selalu terupdate sesuai kebutuhan.

Dari hasil pengujian menunjukkan proses ini data kriteria as pek tanah berhasil sesuai dengan harapan.

Pengujian kedua dilakukan pada proses analisa yang bertujuan untuk menentukan jenis tanaman yang tepat untuk tingkat kesuburan tanah tertentu. Pada pengujian ini pertamatama akan dilakukan perhitungan secara manual untuk mengetahui hasil tanaman yang disarankan, kemudian dari hasil perhitungan manual tersebut akan dibandingkan hasilnya dengan hasil dari sistem. Jika hasilnya sama maka sistem dinyatakan telah berjalan sesuai harapan. Perhitungan manual dilakukan pada setiap kriteria aspek tanah yaitu dengan menggunakan rumus :

$$
\frac{x-a}{b-a}
$$

keterangan :

$\mathrm{x}=$ Nilai inputan

$\mathrm{a}=$ Batas bawah nilai kriteria aspek tanah

$\mathrm{b}=$ Batas atas nilai kriteria aspek tanah

Dimana dalam pengujian ini dimisalkan nilai-nilai unsur aspek tanah adalah :

- Oksigen $\tan a h=40$.

- Keasaman $\tan a h=7$

- Kelembapan Tanah $=75$

- Tekstur Tanah = 0.09 (Pasir Halus)

- $\quad$ Suhu $=18$

Berdasarkan nilai-nilai unsur tanah diatas kemudian dilakukan perhitungan dengan menggunakan rumus 13. Adapun perhitungannya sebagai berikut :

$$
\begin{array}{ll}
\text { Oksigen Tanah } & =\frac{x-a}{b-a}=\frac{40-35}{75-35}=0,125 \\
\text { Keasaman Tanah } & =\frac{x-a}{b-a}=\frac{7-4,5}{7,5-4,5}=0,834 \\
\text { Kelembapan Tanah } & =\frac{x-a}{b-a}=\frac{75-40}{80-40}=0,875 \\
\text { Tekstur Tanah } & =\frac{x-a}{b-a}=\frac{0.09-0.002}{2-0.002}=0,044 \\
\text { Suhu Tanah } & =\frac{x-a}{b-a}=\frac{18-10}{36-10}=0,308 \\
\text { Hasil } & =\frac{\text { Hasil perhitungan perunsur aspek tanah }}{\text { Jumlah unsur aspek tanah }} \\
& =\frac{0.125+0.834+0.875+0.044+0.308}{5}=0,437
\end{array}
$$

Gambar 11. Hasil perhitungan rumus 13

Dari hasil perh itungan diketahui Jenis Tanaman yang tepat adalah tanaman cabai. Selanjutnya akan dilakukan penginputan ada unsur aspek tanah dengan nilai yang sama pada sistem pakar untuk mengetahui hasil dari sistem. Hasilnya sistem pakar juga merekomendasikan cabai, sesuai dengan hasil perhitungan manual.

\section{KESIMPULAN DAN SARAN}

Dalam proses perancangan serta pembuatan aplikasi sistem pakar deteksi tingkat kesuburan tanah ini, dapat diambil kesimpulan bahwa sistem pakar in i dapat memberikan rekomendasi jenis tanaman yang tepat sesuai dengan tingkat kesuburan tanah tertentu menggunakan metode fuzzy logic.

\section{Ucapan Terima Kasih}

Penulis mengucapkan terima kasih kepada dosen dan staf fakultas teknologi informasi Universitas Merdeka Pasuruan serta kepada kepala Kantor Ketahanan Tanaman Pangan Dinas Pertanian Pemerintahan Kabupaten Pasuruan dan kawasan pertanian Kecamatan Kraton, Kabupaten Pasuruan atas bimbingannya dan dukungannya sampai terselesaikannya penelitian ini. Serta terima kasih disampaikan kepada Tim JOINTECS yang telah meluangkan waktu untuk membuat template ini.

\section{DAFTAR PUSTAKA}

[1]. Sarief, Saifuddin. 2000. Ilmu Tanah Pertanian. Penerbit Pustaka Buana: Bandung.

[2]. Kaswidjanti. 2011. Implementasi Mesin Inferensi Fuzzy (Studi Kasus Sistem Pakar Untuk Mendiagnosa Penyakit Tanaman Cabe Merah). Penerbit Fakultas Informatika Universitas Udaya Bandung.

[3]. Winiarti, Sri dan Fitriana. 2014. Sistem Pakar Penentuan Kesesuaian Lahan Pertanian untuk Pembudidayan Tanaman buah-buahan. Penerbit Fakultas Informasi: Universita Mercubuana, Bogor.

[4]. Sugiono. 2008. Panduan Metode Penelitian. Bandung. Alfabeta.

[5]. Afandhie Rosmarkam \& Nasih Widya Yuwono. 2002. Ilmu Kesuburan Tanah.Penerbit Kanisius: Yogyakarta.

[6]. Subroto \& Awang Yusrani. 2005. Kesuburan dan Pemanfaatan Tanah. Penerbit Bayu Media: Malang. 
